\title{
U.S. STRATEGIC CULTURE AND THE GENESIS OF COUNTERINSURGENCY DOCTRINE
}

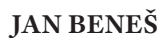

CHARLES UNIVERSITY, PRAGUE

\begin{abstract}
Counterinsurgency (COIN) doctrine is a very special strategy in the art of war, which involves significantly different tactics than does conventional warfare. U.S. doctrine for combat against insurgents has gone through several changes, the most dramatic of which occurred after $9 / 11$, when the U.S. military faced a new kind of enemy: a global network of fighters, often described as a "global insurgency." This paper traces the genesis and further development of modern U.S. COIN doctrine. It asks two main questions: How has U.S. COIN doctrine changed after the 9/11 attack? How have its methods, organization and execution changed during the War on Terror? The author assumes that the driving force behind the development of U.S. COIN doctrine is an inter-subjective interpretation of the enemy, the threats and the situation on the battlefield, which can be described as a "strategic culture." This article uses strategic culture to analyze the genesis and development of modern U.S. COIN doctrine. It also traces the changes in military tactics, strategic priorities and operational procedures that have occurred since $9 / 11$. The author suggests that there have been three phases in the development of U.S. COIN doctrine during the War on Terror: Shock and Awe, Population-centric COIN and Targeted COIN. These phases reveal how the U.S. military has reacted to the emerging challenges it faces.
\end{abstract}

Keywords: United States; counterinsurgency; strategic culture; War on Terror; Afghanistan; Iraq DOI: $10.14712 / 23363231.2017 .18$

This article was written as part of a Specific Academic Research Project of the Institute of Political Studies, Faculty of Social Sciences, Charles University, Prague, No. 260 230/2015, Contemporary Forms of Governance: National, Local, and International Level.

Jan Beneš is a doctoral student in the Department of International Relations at the Charles University, Prague. Address correspondence to Jan Beneš, IPS FSV UK, U Kř́íže 8, CZ-158 00 Praha 5.E-mail: hrh.janbenes@gmail.com. 


\section{Introduction: The Clash with the Global Insurgency}

The doctrine of counterinsurgency appeared at the dawn of the twenty-first century. The U.S. military was facing the task of defining its role at "the end of history." The massive use of aerial bombing was believed to have the capability of solving any international crisis that might appear to threaten regional stability in a unipolar post-Cold War world. Operation Desert Shield proved in the early 1990s that regardless of difficulties of terrain, there is no conventional army in the world that can stand up to the United States in battle and win. After $9 / 11$, the military realized that terrorism, professionally used as a military tactic, can inflict serious damage on even the greatest of adversaries. Additionally, and perhaps more importantly, the military realized that this new enemy could not be defeated by an overwhelming, technologically superior force. The two major conflicts connected with the War on Terror (Iraq and Afghanistan) turned swiftly from classical military campaigns into something the Pentagon had not expected - low intensity conflicts which blurred the lines between politics and warfare. Uncertain distinctions between combatants and civilians and unconventional fighting methods employed by insurgents created new moral dilemmas and required special new skills in which troops had never before been trained. The military environment went swiftly through radical changes. Academics gave the new warfare many names: fourth generation warfare, ${ }^{2}$ new wars $^{3}$ and asymmetrical warfare. ${ }^{4}$ The outcome is nevertheless one that the famous Israeli military theoretician, Martin van Creveld, foresaw immediately after the end of the Cold War. He opened his book on the subject with the following statement: "A ghost is stalking the corridors of general staffs and defense departments all over the 'developed' world - the fear of military impotence, even irrelevance." 5

The post-9/11 enemy is different from anything the traditional military has seen before. The enemy is everywhere and nowhere. The enemy may embark

1 Francis Fukuyama, The End of History and the Last Man (New York: Free Press, 2006).

2 Thomas Hammes, The Sling and the Stone: On War in the 21st Century (Grand Rapids, MI: Zenith, 2006); William S. Lind, “Understanding Fourth Generation War," Military Review 84, No. 5 (2004): 12-16.

3 Mary Kaldor, New and Old Wars: Organized Violence in a Global Era (Stanford, CA: Stanford University Press, 2007).

4 Christopher Coker, Waging War without Warriors? The Changing Culture of Military Conflict (Boulder, CO: Lynne Rienner Publishers, 2002).

5 Martin Van Creveld, The Transformation of War (New York: Maxwell Macmillan International, 1991). 
from any country and strike anywhere at any time. In the past, there were many insurgencies with combatants recruited from civilian populations, wearing no uniforms and appearing and disappearing in difficult environments. Now, Al-Qaeda and hundreds of associated groups, gangs and militias have pushed insurgency to another level. Terrorist cells can be found anywhere, not only in enemy territory or on occupied soil, but also among the society at home. The fundamentalist interpretation of Islam, known in the West as Islamism, together with the anti-Western and anti-establishment message of Al-Qaeda's preachers, has spread all over the Muslim world, inspiring thousands of groups and fighters to start their own insurgencies against the global hegemony of Western thought. Western strategists have realized that those insurgencies are interconnected in an almost impenetrable network of loyalties, messages, trade, training, support, and inspiration. David Kilcullen labeled this phenomenon the "global insurgency." ${ }^{6}$ How to break that network? The Pentagon decided to cut off the head of the snake, by destroying the sanctuaries of the "Al-Qaeda core." The campaign in Afghanistan, and also the campaign in Iraq that followed (regardless of its controversial political nature), has shown that after a short conventional military campaign, the U.S, army is "impotent and even irrelevant" in the effort to destroy the Al-Qaeda network and its allies, stabilize the countries where they hide, and deny them any possible sanctuary. ${ }^{7}$

In an attempt to grasp the fluid nature of modern conflict, regain the initiative, and win, the U.S. military leadership decided to revive counterinsurgency (COIN) theory. A classic military strategy from colonial times has again found a purpose in modern warfare. COIN has become the dominant military activity in the War on Terror. To win the longest war in U.S. history means succeeding at counterinsurgency. One of the key features that COIN strategy offers is flexibility; it reacts to moves by the enemy, and it can adapt to various environments, strategies and adversaries. The doctrine is as fluid as modern conflict itself. ${ }^{8}$ This paper seeks to analyze the genesis and track the development of contemporary U.S. counterinsurgency doctrine from its beginnings at the outset of the War on Terror to the present. Studying modern U.S. counterinsurgency doctrine is vital to understanding twenty-first century security, defense and military strategy.

6 David J. Kilcullen, “Countering Global Insurgency,” Journal of Strategic Studies 28, No. 4 (2005): 597-617, doi: 10.1080/01402390500300956.

7 See "National Strategy for Combating Terrorism (February 2003)," Central Intelligence Agency, https://www.cia.gov/news-information/cia-the-war-on-terrorism/Counter_Terrorism_Strategy .pdf.

8 David J. Kilcullen, Counterinsurgency (Oxford: Oxford University Press, 2010), 2-13. 
COIN doctrine very well reflects U.S. thinking on these matters. Furthermore, it reflects the dynamics of rapidly developing modern military thought itself.

The purpose of this article is to illuminate, explain and contextualize the genesis and evolution of modern U.S. counterinsurgency doctrine. It seeks to clarify how COIN doctrine has changed in terms of methods, organization, and execution during the War on Terror, from its inception to the present.

\section{Conceptual Framework}

This article is based on the assumption that U.S. strategic culture is the driving force behind the development of modern U.S. COIN doctrine. Ontologically, it treats U.S. COIN activity as an objective, observable phenomenon that appeared under specific circumstances in a particular environment. U.S. COIN doctrine is a distinctive military doctrine that has its own internal dynamics, including strategic objectives, operational procedures, range of activities, scope of involvement, and different traditions to which it adheres. The U.S. political and military leadership, as well as the whole strategic community (the top political, military, bureaucratic and academic elites, NGOs and key private sector figures involved in the deliberation of the strategy) run the development of COIN doctrine. The U.S. leadership and those from the strategic community who are involved react to objective political and more importantly, military realities.

Strategic culture can be understood as a kind of lens through which decision-making actors perceive reality. Strategic culture determines how issues are analyzed, understood and transformed into particular decisions and strategies. This research therefore uses U.S. strategic culture to understand how the U.S. reacted to specific political and military situations that appeared during the long years of the War on Terror by tracking the genesis and development of modern U.S. COIN doctrine. Showing the development of COIN in this era is beneficial for understanding the development of the modern military itself.

\section{COIN}

COIN is a military doctrine for combating insurgencies. It is a counter-underdog strategy, which means a strategy developed by "the stronger." A sovereign authority employs it against a non-state, irregular insurgency operating within the territory under the sovereign's control. COIN strategy has been around for centuries, but it was Carl von Clausewitz who elaborated it into a theory of the possible strategies that could be used against insurgents and 
their counterparts. ${ }^{9}$ Later, COIN became an essential part of imperial policies in the late French and British empires. David Galula, a military theoretician and a French colonial officer serving during the Algerian War, created one of the most notable academic traditions of COIN theory. He described COIN as a complex military doctrine, which combines military action with political activity. Simply destroying insurgent forces is never sufficient, he claimed. That destruction must be accompanied by actions centered on gaining the support of the population. It is the population that ensures the survival of an insurgency, and as long as the population favors it, the insurgency cannot be defeated. The heart of COIN therefore lies in a combination of propaganda, institution-building, good governance and military operations to win over the population and disconnect it from the insurgents. ${ }^{10}$

The British military went through many tough struggles with insurgencies, notably in Afghanistan, Sudan, Malaya and Kenya, where the Brits gained experience in executing counter-underdog strategies in varied environments. The British tradition of COIN theory is represented mainly by Robert Thompson and Frank Kitson. It was summarized by the legendary T. E. Lawrence as emphasizing enlightened imperial policies, good governance and a combination of policing, military action, political planning and ideological superiority. ${ }^{11}$ The key difference between the French and British approaches is that aside from military operations, the British focus on strong, effective and credible institutions, while the French approach combines propaganda, humanitarian aid and close contact with the population.

The American COIN tradition dates back to the Indian Wars. Later, during its struggle with the Philippine insurgency, the U.S. successfully combined good governance practices (establishing a university, building and expanding infrastructure) with relatively harsh military methods and the deployment of modern military technologies. ${ }^{12}$

During the Vietnam War, the U.S. military strategically used overwhelming force to repel attacks by the Vietcong. They also adopted strategies to eradicate

${ }^{9}$ Carl von Clausewitz, On War: Sixth Book: Defence (Princeton, NJ: Princeton University Press, 1989).

${ }^{10}$ David Galula, Counterinsurgency Warfare: Theory and Practice (London: Praeger Security International, 2006), 53-59.

${ }^{11}$ Robert F. Thompson, Defeating Communist Insurgency: Experiences from Malaya and Vietnam (London: Chatto \& Windus, 1972), 50-60; Frank Kitson, Low Intensity Operations: Subversion, Insurgency and Peacekeeping (London: Faber \& Faber, 2011).

12 Mike Fowler, "Philippine Counterinsurgency Strategy: Then and Now," Small Wars Journal 7, No. 1 (January 2011): 58-62. 
and clear out insurgents from hostile or potentially hostile territories. Despite efforts to challenge enemy forces with a "fight or run" strategy, forcing the enemy combatants either to fight (and eventually lose) or run (and leave the territory), the U.S. never gained the momentum needed to thwart either small-scale ambushes or major attacks like the Tet offensive. ${ }^{13}$ Later, when this "enemy-centric" COIN seemed to be ineffective, generals Westmoreland and Abrams adopted a more "population-centric" COIN strategy. Despite limited success, they did not manage to reverse the situation. ${ }^{14}$

The U.S. military later achieved minor successes in El Salvador and Lebanon. Before 9/11, U.S. COIN strategic doctrine was still the classic military approach. That approach was enemy-centric, involving massive air strikes, largescale operations, and the deployment of Special Forces.

\section{Strategic Culture}

American strategic culture is a widely-discussed topic. To understand U.S. military development in the twenty-first century, it is necessary to understand U.S. military logic. When classic theories of international relations became insufficient to fully understand a nation-state's strategic choices, Jack L. Snyder of the RAND Corporation followed the lead of classical military theoreticians like Thucydides, Sun-Tzu and Clausewitz, and showed that the Soviet Union was an enemy with its own way of understanding strategic issues in the international arena. He claimed that Soviet elites do not decide solely on the basis of rational choice, but are influenced by intersubjective shared cultural, institutional and ideological background, which has significant impact on their perception of strategic issues. Snyder provides an explanation of Soviet behavior in the strategic field through the concept of "strategic culture." Strategic culture in his view is a distinct mode of strategic thinking shaped by national spirit, history, ideology, organization, relationships between politicians, military and bureaucracy, and shared images of war among the decision makers. ${ }^{15} \mathrm{~A}$ whole generation of authors continued in this effort, using and modifying the concept of strategic culture in an attempt to

13 James M. Bright, "A Failure in Strategy: America and the Vietnam War 1965-1968" (MA dissertation, Quantico: USMC Command and Staff College, 2001), http://www.dtic.mil/dtic/tr /fulltext/u2/a401184.pdf.

${ }^{14}$ John Nagl, Learning to Eat Soup with a Knife: Counterinsurgency Lessons from Malaya and Vietnam (Chicago: The University of Chicago Press, 2002), 168-69.

15 Jack L. Snyder, The Soviet Strategic Culture: Implications for Limited Nuclear Operations (Santa Monica, CA: RAND Corporation, 1977), https://www.rand.org/pubs/reports/R2154.html. 
understand the behavior of various other actors in the sphere of international relations as a culture. Alastair Johnston understood strategic culture as a rejection of acultural and ahistorical conceptions of international relations. According to him, the actors in international relations are not rational players, but are embedded in history, culture and national sentiment. ${ }^{16}$

Andrew Scobell defines strategic culture as a set of "assumptions about the role of war in human affairs and the efficacy of applying force held by a country's political and military elites." 17 It is an intersubjective filter between objective reality and the final decision taken by an elite. Facing the same situation, Russia would react differently than Germany or the United States, because they have different strategic cultures. The actors responsible for their country's strategic choices interpret reality via their strategic culture. Strategic culture is a set of traditions and habits. It includes successful and unsuccessful military tools, strategies, tactics, and operational procedures that impact future decision-making.

\section{U.S. Strategic Culture}

U.S. strategic culture is deeply rooted in exceptionalism. Liberal Protestantism and the exceptional role of America envisaged by "Manifest Destiny" are still strong influences on U.S. foreign policy. ${ }^{18}$ U.S. foreign policy has never been a monolith, but has always varied between several different traditions of interventionism and isolationism, which have been described as the four main archetypes of US foreign policy: Jeffersonian, Jacksonian, Hamiltonian and Wilsonian. ${ }^{19}$ Even though these different foreign policy traditions are based on varying interpretations of the U.S. role in international relations, they can all be traced to a common U.S. strategic culture, especially when war is imminent.

${ }^{16}$ Alastair Iain Johnston, Cultural Realism: Strategic Culture and Grand Strategy in Chinese History (Princeton: Princeton University Press, 1998), 1-22.

17 Andrew Scobell, China's Use of Military Force: Beyond the Great Wall and the Long March (New York, NY: Cambridge University Press, 2003), 2 as quoted by Christopher P. Twomey, "Chinese Strategic Cultures: Survey and Critique" (Report for Defense Threat Reduction Agency, October 31, 2006), 4, https://fas.org/irp/agency/dod/dtra/chinese.pdf.

18 James W. Ceaser, "The Origins and Character of American Exceptionalism. American Political Thought," A Journal of Ideas, Institutions, and Culture 1, No. 1 (Spring 2012): 1-25, doi: $10.1086 / 664595$.

19 Walter Russell Mead, Special Providence: American Foreign Policy and How It Changed the World (New York: Routledge, 2002). 
The U.S. understanding of war has always been very different from the European. Clausewitz defined the classical European understanding of war when he said that war is a "mere continuation of policy by other means." ${ }^{20}$ Americans never viewed war that way. War in the American mind is always a moral act. War can only be waged against evil. War is never waged for power or territory, and it is always a clash between good and evil. If there are any ambitions for power, they are preferably hidden. ${ }^{21}$ The enemy is often described as pure evil, the personification of the devil. In the popular mind, the enemies of the U.S. have been nothing but totalitarian ideologies, ruthless dictators and cruel bandits. The U.S. government was never a monarchy and it therefore couldn't wage war simply on the whim of the king's court - war had to be justified to the public. The only just war, in the American view, is a war on evil. ${ }^{22}$ War is not a continuation of policy, but something very different. War is foreign to the politics of moral men. On the other hand, when one is fighting evil, there is no room for politics. Politics and war are ideologically separate.

Framing war as an act of Christian virtue and a battle with evil has serious strategic consequences. Waging war on evil requires total war. Europeans understand the concept of limited war much better than Americans. They understand that a state may start a war, reach its limited objectives (gain territory, secure its borders) and be done with it. On the other hand, fighting evil does not involve such clear objectives. Allowing evil to survive is hardly moral. The U.S. therefore almost always settles on the objective of total surrender. In other words, it is not enough to get Hitler out of France; he and his armies must be completely destroyed. As long as the Soviet Union existed as an "Evil Empire," the Cold War could never end. This logic creates a problem: producing an effective and credible exit strategy.

Another important aspect of U.S. strategic culture is the impatience of the American public. The U.S. public wants a short war leading to a clear victory. The American people are not willing to sacrifice their soldiers in a war without clear goals, one that has no end in sight or that is based on a crooked pretext. An important election is held every two years, presidential, congressional, or both.

${ }^{20}$ Carl von Clausewitz, On War: A Timeless Analysis of Political-Military Strategy (New York: Skyhorse Publishing, 2013), 36.

${ }^{21}$ Thomas G. Mahnken, "United States Strategic Culture" (Report for Defense Threat Reduction Agency, November 13, 2006), http://www.au.af.mil/au/awc/awcgate/dtra/mahnken_strat _culture.pdf.

22 Glenn A. Moots, “The Protestant Roots of American Civil Religion," Humanitas 23, No. 1-2 (2010): 78-106. 
The President and/or his party are then held accountable for the results of any war they (or their predecessors) have undertaken. ${ }^{23}$ Long-term strategies that require patience, limited goals, complicated strategy, and hard, invisible struggle are therefore unpopular and almost impossible to wage.

Colin Gray contends that the U.S. has always cared mostly about material superiority. The belief that the materially and technologically superior side will inevitably win strongly influences U.S. military thinking. Concern for the allocation of resources, logistics, technology and material support has far exceeded strategic and operational thinking on the battlefield. ${ }^{24}$ Most theoreticians of American military culture point out that it includes the desire to win a war swiftly. ${ }^{25}$ U.S. strategists seek out the decisive battle and then apply massive military force, concentrating most of the deployed military power in combination (aircraft, artillery, ground forces) in order to spectacularly defeat the enemy.

Casualties are another important factor. Most strategic authors write about the unwillingness of the American public to accept casualties. The goal of reducing U.S. casualties and, if necessary, transferring them to the civilian population of a foreign country is crucial to grasping U.S. military thinking. ${ }^{26}$ The famously "tragic" battle in Mogadishu, where the U.S. public could not bear to suffer a mere 18 casualties but did not spare much thought for the more than 500 Somalians who were killed in combat, is a good example. ${ }^{27}$ The effort to avoid U.S. casualties at all costs leads to an abstract vision of a war fought without any casualties. ${ }^{28}$ The acceptance of collateral damage, but refusal to accept U.S. casualties is an extremely important aspect of US strategic culture. ${ }^{29}$

23 David Karol and Edward Miguel, "The Electoral Cost of War: Iraq Casualties and the 2004 U.S. Presidential Election," The Journal of Politics 69, No. 3 (2007): 633-648, doi: 10.1111/j.1468 -2508.2007.00564.x; David R. Mayhew, "Wars and American Politics", Perspectives on Politics 3, No. 3 (2005): 473-93, doi: 10.1017/S1537592705050309.

24 Colin S. Gray, "National Style in Strategy: The American Example," International Security 6, No. 2 (1981), 22.

25 E.g. Russell Frank Weigley, The American Way of War: A History of United States Military Strategy and Policy (Bloomington, IN: Indiana University Press, 1973).

${ }^{26}$ Edward N. Luttwak, “Towards Post-Heroic Warfare," Foreign Affairs 74, No. 3 (May/June 1995), https://www.foreignaffairs.com/articles/chechnya/1995-05-01/toward-post-heroic-warfare.

27 Mahnken, "United States Strategic Culture."

${ }^{28}$ Niklas Schörnig, "The Vision of War without Casualties: On the Use of Casualty Aversion in Armament Advertisements," Journal of Conflict Resolution 50, No. 2 (2006): 204-27, doi: $10.1177 / 0022002705284827$.

29 Although some have argued against this idea - see Richard A. Lacquement Jr., "The Casualty Aversion Myth”, Naval War College Review 57, No. 1 (2004): 39-57; or Timothy S. Mundy, Casualty Aversion: Dispelling the Myth (BiblioScholar, 2012) - their opinions are rather marginal in the field of strategic studies. 


\section{Genesis of U.S. COIN Efforts}

\section{First Phase: Shock and Awe}

Following 9/11, U.S. policymakers held a strong belief that the scenario of the 1991 Gulf War would repeat itself and the renewed war with Iraq and the action in Afghanistan would be quickly over and done with, providing a great story of revenge and justice. The war in Afghanistan in particular was described in strong moral terms, as seen from President Bush's address to Congress on September 20, 2001. To defeat the Taliban, the U.S. decided to use heavy aerial bombardment and proxy forces. The Taliban government in Kabul was overthrown in two months. ${ }^{30}$ However, the Taliban, which represented a brutish tyranny of the worst kind and adhered to the most rigid interpretation of Islam, managed to hang on to control of most of its territory. Despite its cruel form of government, Taliban ended the chaos and imposed a form of rule of law. The government of Hamid Karzai, installed and supported by the U.S. military, was not able to do that where it held sway. ${ }^{31} \mathrm{Al}$ Qaeda survived, as did the radical wings of the Taliban, and the insurgency began.

COIN was supposed to quickly tame the insurgents, who were believed to be merely divided and scattered remnants of the Taliban and Al Qaeda that had survived the decisive battles for Kabul and other major cities. The goal of the American strategy was not to repeat Soviet mistakes. They deployed small units of Special Forces, which were mainly expected to find and destroy high profile terrorists. This strategy, termed the "Light Footprint," was focused on diminishing collateral damage to Afghanistan, reducing casualties, and avoiding alienating the population. ${ }^{32}$

The American military started an intensive program aimed at eradicating the insurgents. Several large-scale operations were conducted to confirm the U.S. victory. In Operation Anaconda, launched in March 2002, the U.S. Army coordinated efforts by intelligence agencies, Special Forces, ground units and strategic and tactical aircraft to purge Afghanistan of the insurgency. Hundreds

${ }^{30}$ Stephen Tanner, A Military History from Alexander the Great to the War against the Taliban (Philadelphia, PA: Da Capo, 2009), 289-321.

31 Seth G. Jones, Counterinsurgency in Afghanistan (Santa Monica, CA: RAND Corporation, 2008), 62-66, https://www.rand.org/pubs/monographs/MG595.html.

32 See Seth G. Jones, In the Graveyard of Empires: America's War in Afghanistan (New York: W. W. Norton, 2010); Robert M. Cassidy, War, Will, and Warlords: Counterinsurgency in Afghanistan and Pakistan, 2001-2011 (Quantico, VA: Marine Corps University Press, 2012). 
of insurgents were killed, hundreds more were cast out of their dens and only eight U.S. soldiers died. ${ }^{33}$

Despite the large-scale military operations, insurgent activity grew rapidly in 2002 and in subsequent years. Islamic insurgents took advantage of the vague Afghani borders and smuggled weapons and explosives into the country. They radicalized people all over Afghanistan, mainly in the southern and north-western parts of the country, and conducted terrorist attacks on U.S. soldiers, government officers, members of the newly established Afghan National Army and the Afghan national police.

Meanwhile, the U.S. launched operation Iraqi Freedom, ousting Saddam Hussein and his regime from Baghdad. Almost 150,000 soldiers were deployed to defeat the Iraqi dictator. ${ }^{34}$ American strategists decided to use the classic doctrine of "Shock and Awe" that had proved successful during the Gulf War in 1991. ${ }^{35}$ However, the unsuccessful post-war administration of Iraq under the Coalition Provisional Authority (CPA) led to an increase in insurgency. ${ }^{36}$ Programs for dissolving the military, de-Ba'athification of government administration, and massive privatization proved problematic for the CPA. These policies were responsible for the collapse of state authority and the rule of law. Insurgents filled the gap. The United States now faced a global insurgency on two major battlefields. The doctrine of shock and awe, which is extremely efficient in situations when a superior force launches a conventional military conflict, was ineffective in what was becoming a long-term engagement.

The U.S. tried to physically and mentally isolate the insurgency from the population. Doing so is a postulate of classic COIN. ${ }^{37}$ The U.S. military command in Iraq decided to use the Light Footprint strategy, using local proxies to isolate the insurgents in the minds of the local population. Psychological operations (PSYOPS) were launched. American PSYOPS depicted the conflict as a battle in black and white by freedom and democracy against darkness, oppres-

33 Richard Kugler, "Operation Anaconda in Afghanistan: A Case Study of Adaptation in Battle" (Case Studies in National Security Transformation No. 5, February 2007), http://ctnsp.dodlive.mil /files/2006/12/Case-5-Operation-Anaconda.pdf.

${ }^{34}$ See Keith L. Shimko, The Iraq Wars and America's Military Revolution (New York, NY: Cambridge University Press, 2010).

35 See Defense Group Inc, Shock and Awe: Achieving Rapid Dominance (Washington, DC: U.S. G.P.O., Superintendent of Documents, 1996).

36 Seth G. Jones, The Rise of Afghanistan's Insurgency: State Failure and Jihad, International Security 32, No. 4 (2008): 26-33, doi: 10.1162/isec.2008.32.4.7.

37 David Galula, Counterinsurgency Warfare: Theory and Practice (Westport, CT: Praeger Security International, 1964); Gordon McCormick, The Shining Path and Peruvian Terrorism (Santa Monica, CA: RAND, 1987), https://www.rand.org/pubs/papers/P7297.html. 
sion and evil. ${ }^{38}$ Massive military operations in mountain areas, deserts and other mostly unpopulated areas, where U.S. intelligence discovered the hideouts of the insurgents, were aimed at destroying what was regarded as an isolated insurgency. This strategy was supplemented with a "search and destroy" approach. "Search and destroy" in this case meant the liquidation of high value targets (political leaders, military commanders, inspirational figures, key sponsors), typically conducted with cooperation between intelligence and Special Forces. Destroying key opposition figures was very important to "winning over" the U.S. public.

These strategies proved to be unsuccessful, however. Support for both wars among the U.S. population was diminishing. ${ }^{39}$ As the number of American and allied casualties grew steadily, the terrorist threat still remained.

\section{Second Phase: A Population-Centric Approach}

The necessity for a change in the strategic course was apparent. The U.S. was stuck in its own strategic culture. The American public, as well as the strategic community, was becoming impatient. Efforts to avoid casualties limited American maneuverability and intensified anxiety that the $9 / 11$ terrorists would go unpunished, leaving the U.S. exposed to a potentially even larger threat.

Proponents of U.S. strategic thinking began looking for solutions. In the ensuing debate, the idea of returning to the roots of COIN doctrine prevailed. In 2006, Gen. David Petraeus issued military handbook, FM 3-24, in which he changed the shape of U.S. COIN efforts in the War on Terror. He proposed a return to the philosophy of Galula and Thompson and other major military thinkers from the golden era of COIN. This new approach favored "population-centric COIN." A need was seen to enhance communication with the local public, highlight the benefits of the foreign military presence, focus on governance, improve cooperation with regional authorities, boost the local economy, and ensure the delivery of basic goods, social welfare, and healthcare services. To put it simply, the insurgents must be disconnected from the population. The U.S. military would win the "hearts and minds" of the people and show them

38 Arturo Munoz, U.S. Military Information Operations in Afghanistan: Effectiveness of Psychological Operations 2001-2010 (Santa Monica, CA: RAND Corporation, 2012), https://www.rand.org/pubs /monographs/MG1060.html.

39 Gallup, War on Terrorism, survey by the Gallup Institute, 2014, http://www.gallup.com/poll /5257/War-Terrorism.aspx\#1. 
that it was committed to protecting civilians and fighting for the interests of the common man. ${ }^{40}$

The manual became the strategic blueprint for this era of COIN. ${ }^{41}$ "Country teams" were created to unify and coordinate efforts to win over the population. COIN would no longer be a solely military matter. It would involve NGOs, the private sector, and the diplomatic corps. ${ }^{42}$

The number of deployed soldiers rapidly increased. They worked closely with private companies, NGOs, regional governments, diplomats and various foreign advisors to build better infrastructure, working sanitation, and affordable housing. In Afghanistan it was necessary to build all basic installations of water, gas, governmental power and public services from the ground up. In the "green zones" the basic foundations of democratic procedures were protected. Between 2006 and 2010, the amount of US development aid to Afghanistan grew more than $400 \% .{ }^{43}$ In Iraq, the situation was different. The country's level of development was much higher. Despite the damage caused to the country by endless fighting since 2003, the overall accessibility of basic services was far ahead of Afghanistan. Combined political/military/NGO teams aimed to mediate the conflicts between Sunnis, Shias and Kurds in the country to create a stable environment. ${ }^{44}$ These efforts were very ambitious. They sought to convince the local population that the U.S. presence was beneficial, strip the insurgents of local population support, and give the War on Terror a humane face in the United States.

In 2008, a new handbook, FM 3-07, was issued. It suggested continuing the population-centric effort, but recommended that local armed forces rather than coalition troops be responsible for public security. ${ }^{45}$ This was a response to the growing number of U.S. casualties and an omnipresent feeling that the war was endless. The American public, many politicians, and Pentagon officials demanded a clear plan for concluding the war. Gen. McChrystal opposed that idea. In 2009, he issued the ISAF Commander's Counterinsurgency Guidance, stating that the current situation in the battlefield simply would not allow a transfer of

${ }^{40}$ David Petraeus, FM 3-24: Counterinsurgency (Washington, DC: Headquarters, Department of the Army, 2006).

${ }^{41}$ David Kilcullen, The Accidental Guerrilla: Fighting Small Wars in the Midst of a Big One (New York: Oxford University Press, 2009), 94-95.

42 Petraeus, FM 3-24: Counterinsurgency.

${ }^{43}$ Kenneth Katzman, "Afghanistan: Post-Taliban Governance, Security, and U.S. Policy" (CRS Report, December 2, 2014), 74.

${ }^{44}$ Ibid.

45 FM 3-07: Stability Operations (Washington, DC: Headquarters, Department of the Army, 2008). 
responsibility to local forces. According to the General, the overall success of COIN depended on the welfare and security of the local population, which could not be maintained by corrupt, ineffective and unreliable local security forces. ${ }^{46}$ He demanded another 40,000 foreign troops for Afghanistan. Development aid grew significantly in an effort to secure population centers and win the hearts and minds of the local population. ${ }^{47}$

Nevertheless, as David Kilcullen points out, there were operational limits to this approach: "Population centers need to be secured 24 hours a day; otherwise, the enemy reinfiltrates the area and intimidates or co-opts the population." 48

Without the omnipresence of coalition forces, the population-centric approach didn't work properly. Often, some local people did identify with the coalition/U.S. effort and embraced their aid and assistance. However, intimidation, terror and sometimes familial and clan affinity with the insurgents were stronger. ${ }^{49}$ This problem became widely known among the U.S. security community. For a long time, the only solution was to increase the number of American personnel on the ground, but the problem never disappeared.

The Obama administration came up with the idea of pulling troops out of a then seemingly stable Iraq and of saving Afghanistan before leaving it. The U.S. presence in Iraq was officially terminated in 2011. Only small teams of guards, political and military advisors and private contractors remained on the ground. On the other hand, the troop presence in Afghanistan was increased. The financial expenses of the Afghan war in 2011 were nearly double what they were in 2008. ${ }^{50}$ The Obama administration also significantly increased the U.S. presence in Afghanistan from 23,700 troops in 2007 to 99,000 in 2011..$^{51}$

Population-centric COIN entailed enormous financial, logistical and, most of all, human costs. The growth in the number of soldiers deployed in Afghanistan and Iraq led to greater casualties. This left the U.S. public with the uneasy feeling that the War on Terror was futile.

46 Stanley McChrystal, “ISAF Commander's Counterinsurgency Guidance,” 2009, North Atlantic Treaty Organization, http://www.nato.int/isaf/docu/official_texts/counterinsurgency_guidance .pdf.

47 Katzman, Afghanistan: Post-Taliban Governance, 74.

48 Kilcullen, The Accidental Guerilla, 94.

49 See David Petraeus, "Learning Counterinsurgency: Observations from Soldiering in Iraq," Military Review 1, No. 1 (January/February 2006): 2-12.

50 Amy Belasco, "The Cost of Iraq, Afghanistan, and Other Global War on Terror Operations Since 9/11" (CRS Report, December 8, 2014), https://www.fas.org/sgp/crs/natsec/RL33110.pdf.

51 Alan McLean and Archie Tse, "American Forces in Afghanistan and Iraq," The New York Times, June 22, 2011, http://www.nytimes.com/interactive/2011/06/22/world/asia/american-forces-in -afghanistan-and-iraq.html. 


\section{Third Phase: Targeted COIN?}

U.S. strategic culture demands visible victory in a short time with few casualties, in a morally undisputable war against evil. The War on Terror cannot possibly offer that combination because the enemy is invisible and the goals and purpose of the war itself are unclear. The U.S. administration and Pentagon strategists thought the War could be waged with limited casualties and could actually end the global insurgency.

A new COIN strategy, with fewer U.S. troops deployed and promising fewer casualties, took off in three main directions. First, there was an effort to transfer responsibility for Iraqi and Afghan security and defense to local armed forces. Second, private contractors increasingly replaced U.S. Army troops. Third, drones were deployed to tame the insurgency's leadership, using targeted killings by remotely controlled machines, guided by intelligence gathering and Special Forces operational groups.

The Bush administration began the transfer of responsibility for security to local governments, but the Obama administration gave that responsibility concrete shape. In a 2009 speech, President Obama announced a plan to withdraw from Iraq, replacing U.S. soldiers with local Iraqi troops. This allowed the United States to boost its engagement in Afghanistan, but with the stated purpose only of preparing for a transition of security duties to the Afghan government. ${ }^{52}$

In his famous article "Learning to Eat Soup with a Knife," COIN theoretician John Nagl stressed the necessity for a gradual transfer to the Iraqis, while keeping responsibility for training and operational planning in the hands of the U.S. That transition, he stated, far exceeded the transfer of responsibility for policing. It required the creation of a legal framework, political authority and reliable governmental policies. ${ }^{53}$ Nagl's recommendations had already been incorporated into the U.S. Army's FM 3-07 stabilization operations manual, which called for the creation of a local force that would use its knowledge of the local environment, culture, language and atmosphere to effectively enforce the rule of law. ${ }^{54}$

The plan failed in many respects. Local forces were corrupt, ineffective, and incapable. They also lacked training, money, experience and, most of all, willingness to serve. Insurgents often managed to infiltrate the newly created armies

52 Barack Obama, “The New Way Forward - The President's Address, 2009," The White House, December 1, 2009, https://www.whitehouse.gov/blog/2009/12/01/new-way-forward-presidents -address.

53 John. A. Nagl, “Learning to Eat Soup with a Knife," World Affairs 161, No. 4 (1999): 193-99.

54 FM 3-07: Stability Operations. 
and police and conduct deadly attacks on coalition troops - so called "green-onblue attacks." 55 In Afghanistan, there was no sense of statehood or state authority. New recruits didn't understand the need for loyalty to the army/police and preferred to remain loyal to their own clans or families. In Iraq, capable and constructive elites were expelled from public life, even as U.S. and Allied training increased the size of the official army by $200 \% .{ }^{56}$ Stabilization operations proved that resisting insurgents was an extremely complicated business. The imperial experience teaches us that building a sustainable security environment is the work of decades, not years.

Another option for increasing forces on the ground was private contractors. In accord with U.S. strategic culture, private contractors were "out of sight" of the media coverage and institutional control, which enabled them to operate in a longer-term framework. Deaths among private contractors are covered up and are not discussed in public debate, ${ }^{57}$ which comports with the usual American intolerance of casualties among actual soldiers. Private contractors are of course a somewhat desperate option. American strategic culture teaches us that the U.S. Army should be the one "righteously" upholding the values of liberty in the dark corners of the world. However, the moral impetus of the campaigns in Afghanistan and Iraq had by then already evaporated and hiring privateers seemed to be a viable solution to the ongoing security problems.

The Bush administration used private contractors to supplement U.S. military involvement. Over time the use of private contractors exceeded the numbers of deployed U.S. troops. In 2008, there were 142,000 U.S. soldiers deployed in Iraq and more than 160,000 private contractors. In 2012, there were 46,000 U.S. troops in Iraq and more than 60,000 contractors. Contractors suffered $64 \%$ of all deaths in Afghanistan. ${ }^{58}$ The U.S. military had difficulty maintaining its control over the contractors, a problem that was never solved satisfactorily. The contractors often used excessive force, causing chaos, frustration, and injustice, which undermined local governments. On the other hand, private companies

55 Ehsan Mehmood Khan, Anatomy of Green-on-Blue Attacks (Islamabad: Pak Institute for Peace Studies, 2012).

56 Obaid Younossi et al., The Long March: Building an Afghan National Army (Santa Monica, CA: RAND Corporation, 2009), https://www.rand.org/pubs/monographs/MG845.html.

57 Micah Zenko, "The New Unknown Soldiers of Afghanistan and Iraq," Foreign Policy, May 29, 2015, http://foreignpolicy.com/2015/05/29/the-new-unknown-soldiers-of-afghanistan-and-iraq/.

58 Defense Science Board, “Contractor Logistics in Support of Contingency Operations" (Report for the U.S. Department of Defense, June 2014), http://www.acq.osd.mil/dsb/reports/CONLOG _Final_Report_17Jun14.pdf; Zenko, "The New Unknown Soldiers"; "Afghanistan Coalition Military Fatalities By Year" and “Iraq Coalition Military Fatalities by Year," http://icasualties.org/. 
like DynCorp did provide successful training and established relatively beneficial relationships with local authorities and security forces. ${ }^{59}$

The use of aircraft diminished over time due to unacceptable levels of collateral damage to local citizens. Collateral damage called into question the moral superiority of the United States and alienated local populations, destroying the effort to implement a population-centric version of COIN. In 2008, an ISAF directive all but forbid aerial support for ground troops. ${ }^{60}$ For this reason, drones largely replaced joint military missions targeting the insurgency's leaders, undertaken by special forces and regular ground troops with massive aerial support.

Although the first drone strikes took place in the early 2000s, it was the Obama administration that significantly expanded the activities of the Joint Special Operations Command (JSOC) and the drone campaign for targeted killings under the supervision and command of the CIA. ${ }^{61}$ The new strategy of COIN was to kill Jihadi leaders, without being present on the ground and without the loss of American lives. Such targeted killing was a solution that corresponded to U.S. strategic culture. Drones were also supposed to cause relatively little collateral damage in comparison to aerial bombing or troop activity on the ground. The U.S. security community sincerely believed that "targeted strikes conform to the principle of proportionality - 'the notion that the anticipated collateral damage of an action cannot be excessive in relation to the anticipated military advantage' - given the precision of the technology." 62

President Bush believed targeted killing of renegade Iraqis showed that the war in Iraq was not being waged against the Iraqi people per se, but against the regime of Saddam Hussein. ${ }^{63}$ Despite one great success, when Al Qaeda leader Osama Bin Laden was killed in 2011, this "decapitation" strategy generated several serious problems.

Although collateral damage from drone attacks is moderate in comparison to the havoc caused by massive military operations, the psychological effect of their use is significant. Drones are an imminent, omnipresent and lasting threat. They exhaust everyone involved and deprive whole populations of a sense of security. Nothing limits the time when drones may attack. Conventional military

59 Christine Fair, "Clear, Build, Hold, Transfer: Can Obama's Afghan Strategy Work?" Asian Affairs 37, No. 3 (2010): 119-23, doi: 10.1080/00927678.2010.503923.

${ }^{60} \mathrm{NATO} /$ ISAF Headquarters, Tactical Directive Afghanistan, Kabul, July 6, 2009, http://www.nato .int/isaf/docu/official_texts/Tactical_Directive_090706.pdf.

${ }^{61}$ Jaclyn Tandler, “Known and Unknowns: President Obama's Lethal Drone Doctrine," Notes de la FRS No. 7 (2013), 1.

62 Ibid., 4.

63 Shimko, The Iraq Wars, 153. 
operations by an army commence and terminate at given times, but drones may fly over the peoples' heads for years, without any foreseeable end. Exhaustion often leads to resignation, anger and the spread of insurgency.

\section{Conclusion}

COIN strategy is an advanced military doctrine that requires complex military thinking. It has been difficult for the U.S. military to succeed in this field. U.S. strategic culture is not suited to COIN. It lacks patience, a sense of detail, the ability to learn, and most of all the ability to admit error. It relies on technological superiority, which is deceptively attractive to military strategists facing a counterinsurgency. It focuses on conventional "Clausewitzian" war. Its exceptionalism, which demands swift and spectacular results, prevents U.S. military strategists from achieving limited victories. ${ }^{64}$ Moreover, the emergence of a global insurgency changed COIN from a series of isolated struggles into a global conflict. Insurgencies have created among their adherents complex networks of loyalties, supply chains, military support, military advisors, messaging, recruitment and preaching. To defeat such a complicated adversary, the U.S. has had to "step out of the box" and start thinking differently.

Modern COIN is a reaction to the urgent need to tame this rising insurgency. Traditional military approaches won in the early stages of the wars in Iraq and Afghanistan, but they failed to keep that victory alive. U.S. commanders, together with the strategic community, based their new COIN strategy on an "enemy-centric" approach which privileged spectacular military action over patient policies of winning over populations. Their new COIN doctrine was embedded in U.S. strategic culture much more than in the earlier traditions of COIN. Modern U.S. COIN doctrine had to develop beyond the enemy-centric approach in order to produce results. This article proposes dividing the genesis and development of U.S. COIN strategy into three simplified phases to help us understand how the U.S. military's thinking progressed. First, the U.S. used its classic set of tools, which had been so successful in the 1991 Gulf War, against insurgents. After that failed, faced with a protracted conflict with "no end in sight," U.S. strategists managed to understand their mistakes and even admit failure. The most progressive military minds like Gen. Petraeus and Gen.

${ }^{64}$ See Robert M. Cassidy, "The British Army and Counterinsurgency: The Salience of Military Culture," The US Army Professional Writing Collection (2005), 115-25, http://www.army.mil /professionalWriting/volumes/volume3/november_2005/11_05_2.html. 
McChrystal tried to learn from the past. They revived old classics like Galula, Thompson and Lawrence, and moved toward a population-centric version of COIN. Population-centric COIN involves a remarkable cooperative effort on the part of the civilian sector, different types of military forces, NGOs, governmental officials, local forces and intelligence. The U.S. adopted new methods despite their military traditions. However, frequent mistakes, the nature of the global insurgency and perhaps even the nature of the War on Terror itself all led to failure. The third phase of COIN doctrine relies on high-tech equipment. It avoids casualties among its own troops by transferring them onto the local population. There is one significant difference between the first and the third phases. The first phase involves open warfare, with clear objectives, U.S. troops on the ground, allied casualties and war heroes. The third phase is a hidden war, one that is undeclared, vague and maybe unending.

Through its changing COIN doctrine, the U.S. military has proved its ability to be creative and to change according to the environment. The U.S. army had to overcome its own strategic culture to adapt to a form of warfare that is in contrast with the U.S. style of waging war. On the other hand, its lack of unqualified success means it has failed to create an example worth following. When future academicians, military theorists and commanders study the U.S. counterinsurgency effort in the War on Terror, they would probably learn more from its mistakes than from its best practices. 